EGALITA, Jurnal Kesetaraan dan Keadilan Gender, Pusat Studi Gender (PSG) Universitas Islam Negeri Maulana Malik Ibrahim Malang. Copyright @ 2009. Vol. IV Nomor 2 Tahun 2009 : 185 - 198

\title{
POLITIK RUANG GENDER PADA PERMUKIMAN Tanevan lanjhang SUMENEP
}

\author{
Pudji Pratitis Wismantara \\ Jurusan Arsitektur UIN Maliki Malang \\ Telepon: 085755218635 \\ E-mail:vismantara@yahoo.co.id
}

\begin{abstract}
Abstrak
For centuries, the discourse of knowledge has been built on the experience, expression of thought, and perception of men about the world. While life experience, ideas, thoughts, and the need of space for women are relatively marginalized. This paper was about to reveal 'symbolic violence' in the understanding and interpretation of settlement space in the public taneyan lanjhang Sumenep Madura. This violence is male initiated by dictating how to think, act, even how to construct a space for women. With the unfolding of 'symbolic violence' in the settlement of this taneyan lanjhang, we must be careful in designing architectural space and try to focus on the designconscious gender
\end{abstract}

Selama berabad-abad, wacana pengetahuan ruang telah dibangun berdasarkan pengalaman, ekspresi pemikiran, dan persepsi laki-laki tentang dunia. Sementara pengalaman hidup, ide, pemikiran, serta kebutuhan perempuan tentang ruang selama ini relatif terpinggirkan. Tulisan ini hendak mengungkapkan 'kekerasan simbolis' dalam pemahaman dan pemaknaan ruang permukiman taneyan lanjhang pada masyarakat Sumenep Madura. Kekerasan ini digulirkan laki-laki dengan mendikte cara berpikir, bertindak, bahkan cara mengkonstruksi ruang kepada perempuan. Dengan terungkap- 
nya 'kekerasan simbolis' pada permukiman taneyan lanjhang ini, kita harus berhati-hati dalam merancang ruang arsitektural dan berusaha memfokuskannya pada desain yang sadar-gender.

Keyword: Politik Ruang, Taneyan lanjhang, 'Kekerasan Simbolis'

\section{Pendahuluan}

Berbagai teori tentang gender mengatakan bahwa terdapat perbedaan hak dan kewajiban antara laki-laki dan perempuan di manapun, disebabkan konstruksi sosial masyarakatnya. Pada umumnya kepentingan laki-laki lebih dinomorsatukan daripada kepentingan perempuan. Hal ini pun terjadi pula pada pewadahan fisik kepentingan itu dalam ruang arsitekturalnya. Ruang merupakan fakta eksistensial, karena kita tak bisa eksis di luar ruang, dan merupakan fenomena yang selalu terbentuk secara sosial dan dinamis (Antariksa, 2001). Segala aktivitas manusia selalu disituasikan dalam ruang tertentu, dengan makna yang berbeda-beda. Ruang tidak bersifat statis dan bukan merupakan sesuatu yang terberi atau ada begitu saja, tetapi selalu terbuka bagi perubahan dan interpretasi. Formasi gender dapat memengaruhi penggunaan dan pengorganisasian ruang. Bagaimana ruang digunakan dan dikonfigurasikan, selalu memaparkan sebuah kisah tentang manusia yang menempatinya.

Rumah sering berati perempuan, dan tempat kerja sering berarti lakilaki. Rumah dianggap sebagai ruang privat di mana perempuan dan anakanak melakukan pekerjaan-pekerjaan yang tidak dibayar. Rumah dikonotasikan dengan nilai-nilai sekunder, seperti perhatian, cinta kasih, kelembutan, dan domestisitas. Sementara tempat kerja berarti laki-laki, tempat melakukan pekerjaan bayaran, dan dikonotasikan dengan nilai-nilai primer, seperti kekuatan, kerja keras, kepemimpinan, dan kenyataan. Ruang-ruang di dalam rumah pada kenyataannya juga dikelaminkan. Misalnya, kamar tidur, dapur dan ruang makan dianggap sebagai ruang perempuan, sedangkan ruang tamu, gudang dan garasi dianggap sebagai ruang laki-laki.

\section{Kerangka Penelitian}

Selama berabad-abad, wacana pengetahuan ruang telah dibangun 
berdasarkan pengalaman, ekspresi pemikiran, dan persepsi laki-laki tentang dunia. Sementara pengalaman hidup, ide, pemikiran, serta kebutuhan perempuan tentang ruang selama ini relatif terpinggirkan. Ruang permukiman etnik Nusantara juga tidak lepas dari konstruksi patriarki , di mana ada pembagian ruang laki-laki dan ruang perempuan. Ruang laki-laki cenderung bersifat formal, strategis, dan digunakan laki-laki untuk mengawasi perempuan. Sementara ruang perempuan berada dalam kondisi serba tertutup, terlindung dan berada dalam posisi yang mudah diawasi. Hal ini menunjukkan bahwa penguasaan ruang -baik publik maupun domestik-- sepenuhnya di bawah kendali laki-laki. Meskipun dalam praksis ruangnya, perempuan diletakkan pada posisi yang terhormat, terlindungi -sesuai dengan wacana patriarkis yang mendudukkan perempuan sebagai makhluk lemah yang harus dilindungi dan dikasih(an)i oleh laki-laki, ia tidak bebas dalam menempati ruang dan tidak terdengar suaranya.

Hal di atas menunjukkan bagaimana 'kekerasan simbolis' (meminjam istilah Pierre Bordieu) telah menjalar dalam praksis dan pengetahuan tentang ruang, dan membuat suara perempuan tidak terdengar. Kekerasan simbolis adalah kekerasan tak kasat mata yang tidak dirasakan sebagai kekerasan, melainkan sebagai sesuatu yang dianggap alamiah dan wajar. Kekerasan ini digulirkan laki-laki dengan mendikte cara berpikir, bertindak, bahkan cara mengkonstruksi ruang kepada perempuan.

Tulisan ini hendak mengungkapkan 'kekerasan simbolis' dalam pemahaman dan pemaknaan ruang permukiman taneyan lanjhang pada masyarakat Sumenep Madura. Ada dua permasalahan Penelitian. Pertama, bagaimanakah budaya patriarki masyarakat Madura mengkonstruksikan ruang permukimannya, dan bagaimana menempatkan perempuan pada ruang permukimannya? Kedua, bagaimana keajegan (continuity) dan perubahan (change) konstruksi permukiman dalam konteks kekinian? Apakah 'kekerasan simbolis' masih tetap ada?

Tujuan Penelitian mencakup dua hal. Pertama, meneropong budaya patriarki dalam mengkonstruksikan pemahaman dan pemaknaan ruang permukiman taneyan lanjhang Sumenep, Madura. Kedua, meneropong sejumlah keajegan dan perubahan ruang taneyan lanjhang dalam konteks kekiniannya, untuk menelusuri masih ada atau tidaknya 'kekerasan simbolis' dalam praksis ruangnya. Kontribusi Penelitian yang ingin dicapai adalah, pertama, dapat menunjukkan 'kekerasan simbolis' ruang permukiman 
taneyan lanjhang Sumenep. Kedua, mengatasi 'kekerasan simbolis di atas dalam suatu perancangan ruang arsitektural yang membebaskan, non-seksis , dan menempatkan perempuan -di samping laki-laki- sebagai subjek yang bersuara.

Kajian ini menggunakan metoda penelitian kualitatif dalam perspektif etnografi arsitektural melalui pendekatan teori kritis sebagai alat tinjaunya. Upaya perumusan sistem ini terbagi menjadi dua langkah, yaitu: Jelajah Spatialitas dan Kajian Sistem Pemaknaan pada permukiman Taneyan. Dengan demikian, 'kekerasan simbolis' pada permukiman taneyan lanjhang bisa terungkap, dan berusaha mengatasinya dalam suatu rancangan yang mengembangkan prinsip nilai sadar gender dalam perwujudan kontekstual dan inovatif rancangan arsitektur berikutnya.

\section{Konstruksi Ruang}

Rumah sebagai lingkungan yang paling diakrabi manusia adalah ranah domestik yang sarat akan makna karena di lingkup terdekat itulah gagasangagasan utama kebudayaan diproduksi. Sumber kekuatan simbolis rumah tidaklah terletak pada rumah sebagai entitas yang terisolasi, melainkan dalam berbagai hubungan antara rumah dan orangorang di dalamnya. Pierre Bordieu (via Dovey, 1999), menganggap rumah sebagai tempat utama bagi obyektifikasi skema generatif suatu budaya. Makna yang diobyektifikasi dalam berbagai benda atau bagian ruang sepenuhnya dihasilkan hanya melalui practices (tindakan-tindakan yang telah menjadi kebiasaan) yang distrukturkan menurut skema yang sama, yang diorganisasikan dalam hubungannya dengan tindakan-tindakan tersebut. Roxana Waterson (1989) menyatakan bahwa aturanaturan penggunaan ruang memberikan jalan yang paling penting bagi pemaknaan lingkung-bina; sebaliknya lingkungan itu sendiri membantu untuk membentuk dan mereproduksikan pola-pola hubungan sosial tertentu. Sehingga secara umum, praktek-praktek, konstruksi material, dan sistem makna saling menguatkan secara timbal balik.

Guna mendeskripsikan keterkaitan yang erat antara tempat dan aktivitas manusia di dalamnya, dalam kajian ini dipergunakan konsep seting perilaku (behavior setting) yang merupakan kombinasi yang stabil antara aktivitas dan tempat. Jon Lang (1987) mengidentifikasikan penyusunan suatu seting perilaku yakni: tindakan berulang yang membentuk pola perilaku, susunan lingkung-bina tertentu yang membentuk milieu, yaitu hubun- 
gan yang kongruen antara keduanya dan kerangka waktu tertentu. Hal ini berarti suatu seting fisik tertentu dapat menjadi bagian dari seting perilaku yang berbeda apabila terdapat pola perilaku yang berbeda pada saat yang berbeda.

Gidden (via Antariksa, 2001) memperkenalkan konsep wilayah depan dan wilayah belakang untuk mengilustrasikan perbedaan-perbedaan fundamental dalam aktivitas sosial-spasial. Ruang depan adalah'panggung' atau 'layar' di mana sebuah pertunjukan ditampilkan di hadapan publik. Ruang depan hanya menampung aktivitas-aktivitas formal, maskulin, dan yang bisa diterima secara sosial. Ruang belakang adalah wilayah ketika kita berada di belakang layar atau panggung, menyiapkan pertunjukan untuk publik, atau ketika kita dapat bersantai dalam perilaku dan pembicaraan yang kurang formal, dan bersifat feminin. Pembedaan antara ruang depan dan belakang atau penggunaan yang dianggap tepat atas ruang tamu, ruang makan dan kamar tidur, semuanya bersifat kultural. Setiap budaya merancang rumah dengan cara berbeda, tergantung pada alokasi makna atau bentuk-bentuk tindakan yang dianggap tepat.

\section{Gambaran Umum Taneyan lanjhang}

Kondisi geografis Madura yang gersang, terdiri dari kawasan dataran rendah pesisir dan pedalaman berbukit-bukit, menciptakan karakteristik asli masyarakatnya yang cenderung individual centered. Karakter ini berpengaruh pada penciptaan pola ruang permukiman yang terpencar dan mengelompok dalam skala kecil (Kuntowijoyo, 1993). Salah satu pola permukiman yang masih banyak ditemui pada saat ini adalah taneyan lanjhang yang secara harafiah berarti permukiman berhalaman panjang. Pola permukiman ini adalah suatu kumpulan rumah yang terdiri atas keluarga-keluarga yang mengikatnya. Letaknya sangat berdekatan dengan lahan garapan, mata air atau sungai. Antara permukiman dengan lahan garapan hanya dibatasi tanaman hidup atau peninggian tanah, sehingga masing-masing kelompok menjadi terpisah oleh lahan garapan. Satu taneyan lanjhang terdiri atas dua sampai sepuluh rumah yang dihuni sejumlah keluarga batih yang terdiri dari orang tua, anak, cucu, dan seterusnya.

Deretan rumah disusun berdasarkan hirarki dalam keluarga. Barattimur adalah arah yang menunjukkan urutan tua-muda. Di ujung paling barat terletak langghar yang merupakan kiblat orang Islam ketika melak- 
sanakan shalat, selain juga berfungsi sebagai tempat untuk menerima tamu laki-laki. Bagian utara merupakan kelompok rumah yang tersusun sesuai hirarki keluarga. Susunan barat-timur terletak rumah orang tua, anak-anak, cucu-cucu, dan cicit-cicit dari keturunan perempuan. Sistem yang demikian mengakibatkan ikatan kekeluargaan menjadi sangat erat, sedangkan hubungan antar kelompok sangat renggang karena letak permukiman yang menyebar terpisah.

Di dalam masyarakat Madura, garis keturunannya adalah matrilineal. Hal ini tampak pada tata atur dan kepemilikan rumah. Permukimannya identik dengan perempuan dan dimiliki bersama, artinya perempuan adalah pemilik sekaligus pemakai rumah, tetapi suatu saat pemakai rumah bisa berpindah saat seniornya meninggal dan yang lebih muda akan menempati rumah yang lebih tua. Senior berkewajiban terhadap kesejahteraan juniornya. Meski demikian, setiap taneyan memiliki pimpinan/ketua yaitu kepala taneyan yang biasanya dijabat oleh laki-laki. Dalam sistem perkawinan, taneyan lanjhang mencerminkan kombinasi antara uxori-local dan matrilocal atau uxorimatrilocal. Artinya anak perempuan yang telah menikah tetap tinggal di pekarangan orang tuanya, sementara anak lelaki yang sudah menikah akan pindah ke pekarangan istri atau mertuanya (Wiyata, 2002).

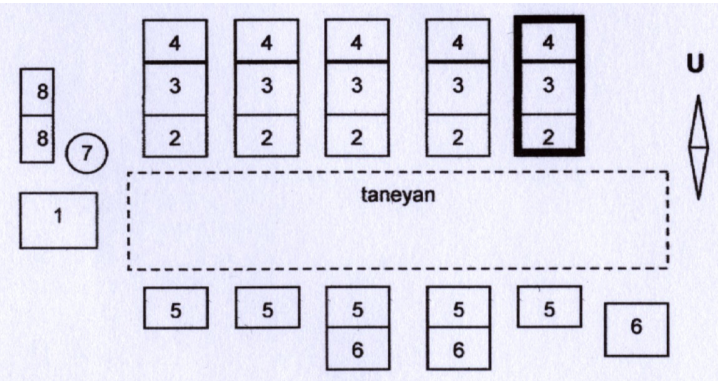

Gambar 1

Formasi Taneyan Lanjhang di Sumenep (dokumen pribadi)
1. Langghar
2. Amper
5. Pandappa
3. Delem
6. Kandang
4. Dapor
7. Sumur
8. $\mathrm{KM} / \mathrm{WC}$

Roma 


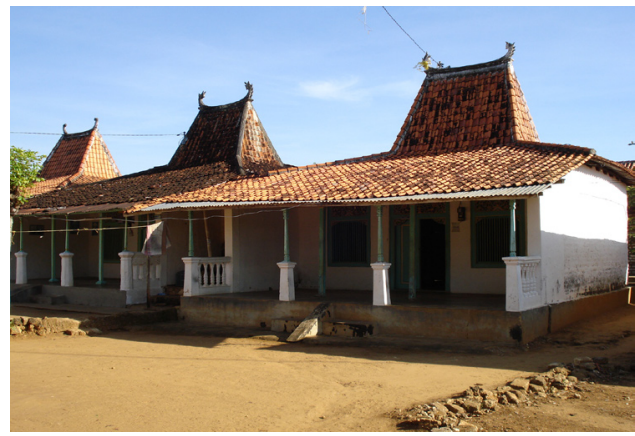

Gambar 2

Permukiman Taneyan Lanjhang Keluarga Munir di Kecamatan Ganding, Sumenep (dokumen Pribadi)

Terbentuknya permukiman taneyan diawali dengan sebuah rumah induk (roma tongghu), sebuah rumah cikal bakal suatu keluarga, yang dilengkapi dengan langghar (barat), kandang (selatan) dan dapor (Wirjoprawiro, 1989). Apabila sebuah keluarga memiliki anak perempuan yang akan berumah tangga, maka orang tua harus membuatkan rumah yang ditempatkan pada posisi di sebelah timurnya, dan anak perempuan yang lain dibuatkan rumah di sisi timurnya lagi dan begitu seterusnya. Apabila deretan rumah terlalu panjang maka susunan dilanjutkan menjadi berhadapan dengan dipisahkan oleh halaman (taneyan). Urutan susunan rumah tetap dimulai dari ujung barat kemudian berakhir di ujung timur.

\section{Jalinan Makna dalam Pembentukan Taneyan lanjhang}

a. Struktur Ruang Hunian Keluarga Inti

Dalam setiap hunian pada taneyan, terdapat prinsip struktur ruang mikrokosmisdualitis yang membagi ruang menjadi wilayah depan (amper) dan wilayah belakang (delem). Wilayah depan (amper) memiliki orientasi keluar, berfungsi sebagai peneduh, tidak dibatasi "enclosure" masif, sehingga terjadi resonansi getar ketenagaan antara seseorang yang memiliki berinteraksi dengan tempat yang dipijaknya beserta lingkungan sekitarnya. Dengan menduduki wilayah depan, seseorang merasa menguasai dan mengorientasikan dirinya atas tempat ini sekaligus membuat batasan dengan lingkungkitarnya yang masih terlihat secara visual. Laki-laki berhak duduk di amper sebagai perwakilan dari keluarga inti dalam menghadapi 
orang lain. Dalam konteks ini, perempuan mungkin terpinggirkan dalam hubungan-hubungan sosial yang formal karena amper menjadi bagian dari milik laki-laki yang notabene tidak memiliki ruang tidur permanen.

Wilayah belakang memiliki orientasi ke dalam, berfungsi sebagai pelindung, dan dibatasi oleh "enclosure" masif, sehingga seseorang yang mendiaminya mulai beralih mengaktifkan kesadaran spiritualnya. Memasuki wilayah belakang berarti memutus interaksi seseorang dengan tempat yang dipijaknya dan sekaligus mengaktifkan "ruang" spiritualitas Adikodrati. Aktifitas tidur menempati wujud spasial delem sebagai kamar tidur yang mengimplikasikan keabadian. Kegiatan berbaring merupakan posisi yang diasumsikan saat suami-istri melakukan hubungan seksual untuk memproduksi kehidupan. Perempuan menikmati hak istimewa untuk memiliki dan menempati delem sebagai bagian yang tersembunyi dari rumah, khususnya beristirahat di malam hari.

\begin{tabular}{|l|l|}
\hline \multicolumn{1}{|c|}{ Amper } & \multicolumn{1}{c|}{ Delem } \\
\hline Area laki-laki & Area perempuan \\
\hline Aktivitas duduk & Aktivitas tidur \\
\hline Orientasi keluar & Orientasi ke dalam \\
\hline Bersifat publik dan formal & Bersifat privat dan intim \\
\hline Terbuka dan terang & tertutup dan gelap \\
\hline Ruang profan & Ruang sakral \\
\hline Simbol kesementaraan & Simbol keabadian \\
\hline ternaung & terlindung \\
\hline Kegiatan beraktivitas & $\begin{array}{l}\text { Kegiatan penyimpanan, } \\
\text { termasuk penyimpanan tubuh } \\
\text { kala tidur }\end{array}$ \\
\hline
\end{tabular}

Tabel 1

Perbedaan Bena antara Amper dan Delem

pada Hunian (Roma) Sumenep, Madura

Kategorisasi utama hubungan sosial adalah antara hubungan-hubungan yang berorientasi keluar dan kedalam. Seseorang melibatkan dirinya dalam hubungan sosial dengan orang lain guna memosisikan status relatif dirinya dengan orang lain. Bagian dalam hunian (delem) adalah wilayah seseorang 
untuk menarik dirinya dari keterlibatan personal dalam dunia luas, guna mengakumulasikan kekuatan dalam dirinya. Bagian depan hunian merupakan wilayah yang berorientasi keluar, tempat prestise domestik dan keteraturan sosial ditampilkan dalam bentuk status dan formalitas.

b. Taneyan lanjhang dan Pola Pertapakannya

Meskipun pemilik utama taneyan adalah kaum perempuan (bersifat matrilineal, pewarisan kepemilikan taneyan pada garis keturunan perempuan), secara umum ia hanya menguasai beberapa bagian taneyan, seperti delem, dan dapor yang memiliki orientasi ke dalam. Bagian taneyan lain yang menunjukkan orientasi keluar, penguasaannya dipercayakan kepada ketua atau pemimpin keluarga taneyan beserta para suami.

\begin{tabular}{|l|l|}
\hline \multicolumn{1}{|c|}{ Langghar-Taneyan } & \multicolumn{1}{c|}{ Delem-Amper } \\
\hline Penguasaan laki-laki & Penguasaan perempuan \\
\hline Aktivitas mengawasi & Aktivitas diawasi \\
\hline Orientasi keluar & Orientasi ke dalam \\
\hline Bersifat publik & Bersifat privat \\
\hline Terbuka dan terang & Tertutup dan gelap \\
\hline Melindungi & Dilindungi \\
\hline
\end{tabular}

Tabel 2

Perbedaan Kepemilikan Pola Tapak antara Langghar-Taneyan dan Delem-Amper pada Permukiman Taneyan Sumenep, Madura

Dalam banyak kesempatan, ketua taneyan selalu berada di langghar, yang selain untuk aktifitas ibadah sehari-hari, juga berfungsi sebagai tempat kegiatan keseharian bagi laki-laki yang sangat strategis untuk pengawasan seluruh bagian taneyan. Ketua taneyan bertanggung jawab sebagai pemantau atau pengawas seluruh anggota keluarga taneyan dan menjamin keamanan dari penetrasi gangguan yang muncul dari luar. Menurut Mansurnoor (1990), surau memiliki fungsi strategis bagi laki-laki untuk mengawasi perempuan. Konsep permukiman ini merupakan wujud perlindungan sesuai mekanisme kontrol laki-laki terhadap perempuan.

Dalam wilayah domestik, perempuan hanya menguasai delem dan 
dapor yang memiliki orientasi ke dalam: mengakumulasikan potensi diri keluarga inti. Perempuan bukan hanya memelihara pusat-pusat kekuasaan domestik yang tersembunyi, tetapi juga yang paling berhak atas ruang tersebut. Pengasosiasian perempuan dengan hunian tempat tinggal harus dipandang setara dengan peminggiran laki-laki dari (inti) hunian.

\section{Pergeseran Pemaknaan Struktur Ruang Taneyan}

Di masa kini terdapat perubahan gaya hidup dan struktur hunian keluarga inti. Unsur-unsur terpenting hunian banyak diubah oleh para pemiliknya, disesuaikan dengan kebutuhan para penghuninya. Dalam kasus pengembangan hunian baru di lahan taneyan, gagasan kultural yang dalam beberapa hal mencerminkan tradisi, masih bisa dikenali dan direproduksi dalam perwujudan baru yang mengkini.

Pertama, pada taneyan di wilayah non-santri, hunian kepala taneyan (sebagai pemimpin) menempati posisi strategis di dekat pintu masuk taneyan. Hunian ini dengan demikian merupakan tempat pengawasan strategis, tempat penyeleksian siapa saja yang boleh masuk, sekaligus tempat penahan penetrasi orang luar ke dalam yang punya maksud jahat.

Kedua, hunian (roma) yang awalnya terdiri dari amper dan delem mengalami transformasi susunan ruang menjadi lebih kompleks, mengikuti perkembangan zaman. Meski demikian, susunan ruang kompleks ini masih menunjukkan cermin ide lama dari gagasan kultural yang direproduksi dalam perwujudan baru. Misalnya dalam satu hunian terdapat banyak delem (kamar) yang memiliki amper dalam bersama (hasil dometifikasi) dan amper luar bersama. Pola pembagian wilayah amper-delem-dapor atau area laki-laki-perempuan masih dipertahankan keberadaannya dalam wujud eksagerasi dan penambahan ruang yang lebih kompleks.

Ketiga, tampilan langghar pada sejumlah taneyan merubah bahan bangunan pembentuknya menjadi lebih permanen. Fungsinya mengalami penyempitan, hanya sekadar tempat shalat dan menerima tamu saja, dan tidak lagi menjadi satu-satunya tempat strategis untuk melakukan pengawasan atas setiap jengkal taneyan. Bahkan pada beberapa tempat terjadi "penghilangan" langghar, karena aspek kepraktisan, ibadah shalat bisa dilakukan di dalam hunian. Bertambahnya hunian juga mendorong perubahan dari langghar yang terpusat menjadi langghar yang tersebar.

Keempat, mulai munculnya kegiatan komersial di ranah taneyan. Banyak 
pemilik hunian yang menambahkan warung, toko, atau bengkel. Ruang ini bisa menempati bagian pintu masuk taneyan. Ada juga hunian yang memiliki dua arah hadap, yaitu amper yang menghadap taneyan dan ruang komersial di belakang roma yang menghadap akses jalan umum. Di sini, peran perempuan dalam kegiatan ekonomi menemukan bentuknya, di mana warung atau toko berfungsi sebagai tempat interaksi sosial-ekonomi dengan masyarakat di ranah publik. Meskipun demikian, ruang ini masih bisa dikendalikan melalui pengawasan dan pengendalian kepala taneyan (yang notabene laki-laki).

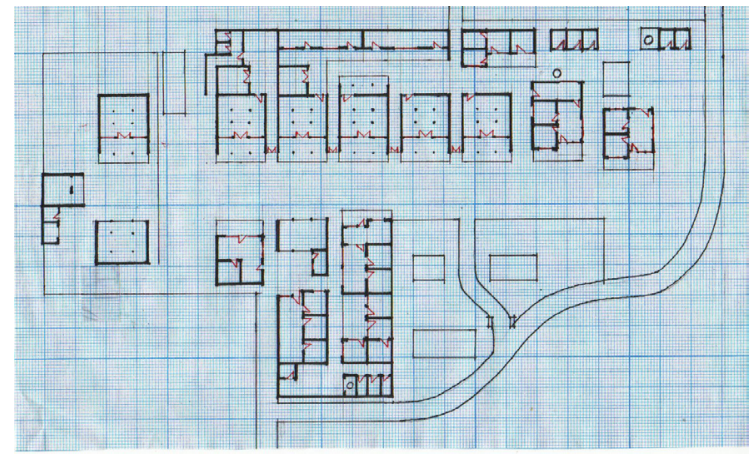

Gambar 3

Tapak Permukiman Taneyan Lanjhang di Wilayah Santri milik Keluarga Munir di Kecamatan Ganding, Sumenep (dokumen Pribadi)

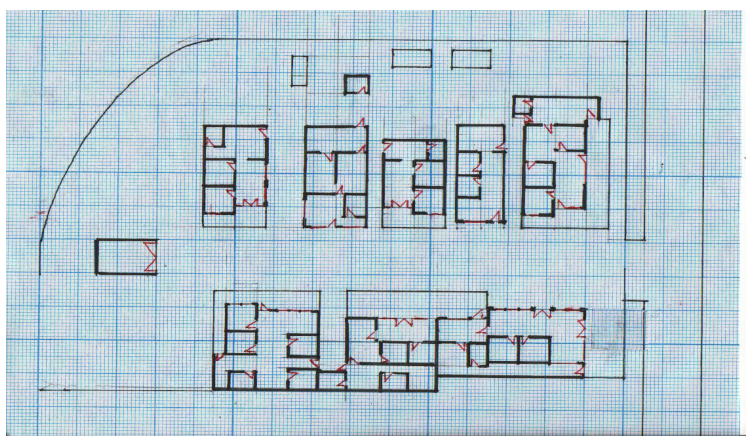

Gambar 4

Tapak Permukiman Taneyan Lanjhang di wilayah Non-Santri milik Keluarga Abdul Kamar di Kecamatan Kalianget, Sumenep (dokumen Pribadi) 
Kelima, penggunaan ruang dapor bersama pada beberapa keluarga inti dalam satu taneyan, yang mensyaratkan luasan dapor yang besar dan umumnya terletak di belakang roma. Aspek yang melatarbelakangi pemakaian dapur bersama ini adalah anjuran ajaran Islam untuk selalu peduli dengan tetangga kiri kanannya. Pada umumnya, di taneyan di wilayah santri berlaku usaha kerjasama secara kolektif sehingga seluruh penghuni merasakan kesejahteraan yang sama. Ruang dapor ini merupakan ruang inti perempuan, di mana semua perempuan yang menghuni taneyan berkumpul dan menghabiskan waktu yang cukup lama di area ini dalam keseharian. Letaknya yang berada di belakang roma menjadikan area ini bersifat privat dan tersembunyi dari jangkauan visual masyarakat sekitar.

Keenam, meskipun tetap mempertahankan halaman utamanya, pada beberapa taneyan terdapat upaya untuk menambahkan halaman-halaman tambahan. Pada gambar 3, penambahan halaman baru terlihat pada wiayah antara roma dengan dapor bersama. Penambahan ini selain untuk kenyamanan sirkulasi udara bagi paraibu pengguna dapur, juga dimanfaatkan untuk tempat bermain anak-anak yang mudah pengawasannya dari arah dapor. Halaman ini menjadi penting sebagai tempat bersosialisasi antar ibuibu dalam aktifitas domestik sehari-hari. Halaman baru bisa ditambahkan secara tegak lurus dengan taneyan sebagai lorong yang menghubungkan hunian baru beberapa keluarga inti. Taneyan tambahan (yang diperuntukkan bagi perempuan) ini terletak di bagian dalam atau belakang gugusan roma, sehingga bersifat privat dan terlindung dari pandangan mata masyarakat sekitarnya. Taneyan lain juga mengalami penambahan halaman untuk akses menuju hunian keluarga inti baru, yang semakin bertambah. Pola penambahan halaman ini bersifat organik dan tidak mengikuti kaidah tata atur taneyan lanjhang. Penambahan halaman beserta hunian inti baru masih tetap terkendali karena mendasarkan perencanaannya pada ijtihad seluruh penghuni taneyan yang membawa pada kemaslahatan bersama, demi perbaikan lingkungan.

Penutup: Sub-Ordinasi Perempuan pada Permukiman Taneyan lanjhang Alam pikiran orang Madura dalam tata kehidupannya memiliki keteraturan yang terstruktur. Hal ini dapat dilihat pada penerapan kosmologi-dualistis pada huniannya. Hunian yang terdapat pada taneyan terdiri dari, bagian belakang yang berorientasi ke dalam dan berfungsi mengakumulasikan 
potensi diri, dan bagian depan yang berorientasi ke luar dan berfungsi mengejawantahkan potensi diri keluar. Ada keterjalinan kompleks antara dua elemen ini yang berperan dalam membentuk hubungan-hubungan sosial antar semua anggota taneyan. Hubungan-hubungan keluar bersifat maskulin, formal dan berjarak, sedangkan ke dalam bersifat feminin, intim dan tidak formal.

Meskipun masyarakat Sumenep Madura menganut sistem kekerabatan matrilineal , konstruksi ruangnya masih menunjukkan sifat androsentrisme , di mana terdapat dominasi nilai budaya yang didasarkan pada norma lakilaki. Dalam perjalanan waktu hingga saat ini, 'kekerasan simbolik' masih tetap melekat pada permukiman taneyan lanjhang. Kekerasan ini ditunjukkan melalui penguasaan, pengawasan dan kontrol ruang permukiman yang sepenuhnya di bawah kendali lakilaki, yang dikepalai oleh kepala taneyan. Meskipun perempuan diberikan keleluasaan dalam memanfaatkan ruang, baik taneyan maupun ladang di sekitarnya, mereka masih didudukkan sebagai objek yang lemah sehingga harus berada dalam posisi yang mudah diawasi. Meskipun dalam praksis ruangnya, perempuan diletakkan pada posisi yang terhormat, terlindungi sesuai dengan wacana patriarkis yang mendudukkan perempuan sebagai makhluk lemah yang harus dilindungi, dikendalikan dan dikasih(an)i oleh laki-laki pada ruang yang terkonstruksi secara patriarki, ia tidak bebas dalam menempati ruang karena selalu diawasi keberadaannya. 'Suara perempuan' untuk ikut mengkonstruksi ruang hidupnya menjadi terbungkam dan tak bisa didengar.

Dengan terungkapnya 'kekerasan simbolis' pada permukiman taneyan lanjhang ini, langkah ke depan kita harus berhati-hati dalam merancang ruang arsitektural dan berusaha memfokuskannya pada desain yang sadargender. Rancangan yang berwawasan gender tidak sekadar rancangan yang ramah perempuan, tetapi juga harus mengembangkan prinsip nilai sadar gender dalam perwujudan yang kontekstual dan inovatif. Rancangan ini harus mengatasi 'kekerasan simbolis' dengan cara mengakomodasi 'suara perempuan' dan 'suara laki-laki' sekaligus dalam kedudukan yang sejajar, dan memberikan akses yang sama bagi kedua gender tersebut. 


\section{DAFTAR PUSTAKA}

Afifi, Mohammad. 14 Juli 2007. Ul-Gaul: Musik Tradisional Kontemporer Madura. Rubrik Khasanah Media Indonesia.

Antariksa. Maret 2001.Politik Ruang. Newsletter Kunci, Edisi 9, Jogjakarta.

Dovey, Kim. 1999. Framing Places: Mediating Power in Built Form, London: Routledge.

Humm, Maggie. 2002. Ensiklopedia Feminisme. Terjemahan oleh Mundi Rahayu. Fajar Pustaka Baru.

Jonge, Huub de. 1989. Madura dalam Empat Zaman: Pedagang, Perkembangan Ekonomi dan Islam. Jakarta: Gramedia.

Kuntowijoyo. 2002. Madura: Perubahan Sosial Masyarakat Agraris. Jogjakarta: Mata Bangsa,

Lang, Jon. 1987. Creating Architectural Theory. New York: Van Nostrand Reinhold Inc.

Mansurnoor, lik Arifin. 1990. Islam: in Indonesian World Ulama of Madura. Yogyakarta: Gadjah Mada University Press.

Rahman, Jamal D. 28 April 2007. Polarisasi Kesenian Madura. Rubrik Khasanah Media Indonesia.

Rivai, Mien Ahmad. 2007. Manusia Madura. Jogjakarta: Pilar Media.

Tulistyantoro, Lintu. 2005. Makna Ruang pada Tanean Lanjang di Madura. Surabaya: Lembaga Penelitian Universitas Kristen Petra.

Waterson, Roxxana. 1989. Living House: the Anthropology of Architecture in South east Asia. Singapore: Oxford University Press.

Wirjoprawiro, Zein Mudjiono. 1989. Arsitektur Tradisional Sumenep Madura. Surabaya: Bina IImu.

Wiyata, A. Latief. 2002. Carok: Konflik Kekerasan dan Harga Diri Orang Madura, Jogjakarta: LKiS. 